\title{
ELECTRONICS
}

UDC 621:314 (045)

DOI:10.18372/1990-5548.65.14990

${ }^{1}$ O. S. Yama,
${ }^{2}$ D. A. Mykolaiets

\section{CONTROL OF THREE-PHASE THREE-LEG INVERTER WITH USING A GEOMETRIC APPROACH}

\author{
${ }^{1,2}$ Department of Electronic Devices and Systems, Faculty of Electronics National Technical University \\ of Ukraine "Igor Sikorsky Kyiv Polytechnic Institute", Kyiv, Ukraine \\ E-mails: ${ }^{1}$ alexei.yama@gmail.com ORCID 0000-0002-9234-1990 \\ 22.mykolaiets@kpi.ua ORCID 0000-0002-9152-8593
}

\begin{abstract}
To build various power supply systems, it is necessary to design a control system that would ensure electromagnetic compatibility with both the load and the source. It is proposed to apply the geometric approach to describe semiconductor power converters, which allows using input independent variables to control the output parameters. The analysis of a three-phase three-leg inverter with a symmetrical active load using a geometric approach is considered. A system of vectors is constructed on which the vectors of input values in three-dimensional space and their projections are shown, which form output values in two-dimensional and one-dimensional space. A table has been created that describes the values of currents and voltages in the converter for the corresponding switch states. Three basic vectors were selected, with the help of which all other vectors of input quantities can be obtained. Transition matrices for the input current and output voltages are obtained. An autonomous inverter control system is built using a geometric approach. The basis is a space-vector pulse-width modulation, with some changes. As a result, the problem of losing the degree of freedom by abandoning the polar coordinate system when switching to another reference system was solved. The solution was the introduction of a spherical coordinate system, which allows you to rotate the control vector in three-dimensional space. As a result, time diagrams of output voltages and currents corresponding to the theoretical ones are obtained. Most units in the control system under the mask implement the program code MATLAB: the transition from a three-dimensional Cartesian coordinate system to a rotating spherical, sector selection, the length of the reference vector and the value of angle, the duration of pulse-width modulation for each sector. The shape of the output voltages has a stepped shape. The shape of the generated currents repeats the shape of the output voltages.
\end{abstract}

Index Terms-Geometric approach; three-phase inverter; system of orthogonal vectors.

\section{INTRODUCTION}

To build a wide range of power supply systems, such as: frequency converters for controlled $\mathrm{AC}$ drive, power supply systems from renewable energy sources - windmills and solar panels, widely used three-phase stand-alone inverter [1], [6], [7], [10]. In some cases, such an application requires the formation of not only the output sinusoidal voltage of constant amplitude and frequency, but also a constant input current of a given value. Another task is to ensure higher stability of the system, which is realized by adding more feedback [5]. Earlier, authors [2]-[5], [8], [9] have proposed the application of a geometric approach to describe semiconductor power converters, which allows using input independent variables to control the output parameters. The article [3] for the first time presents the principle of analysis of semiconductor converters using a geometric approach. The article [2] presents the analysis of a single-phase inverter, the input parameters of which form a two- dimensional coordinate system. In articles [4], [5], [9] the analysis of the matrix converter is presented, and in [8] - the three-phase power active filter. From the analysis of these sources we can conclude that the problem of constructing relationships for a threephase bridge inverter, as well as building a control system to ensure the simultaneous formation of the required output voltage and DC current consumption was not considered. Thus, the task of this work is to derive the basic relations between the input and output parameters of a stand-alone inverter using a geometric approach.

\section{APPLICATION OF GEOMETRIC APPROACH}

Figure 1 shows a simplified diagram of a standalone inverter with a symmetrical active load. For further analytical calculations, we use active resistance as a load, because when analyzing an electric model with a real load, such as an induction motor, it is necessary to derive differential equations of the first, second or higher orders. This type of load is chosen to demonstrate the method of 
constructing the relationship between input parameters and output, using a geometric approach.

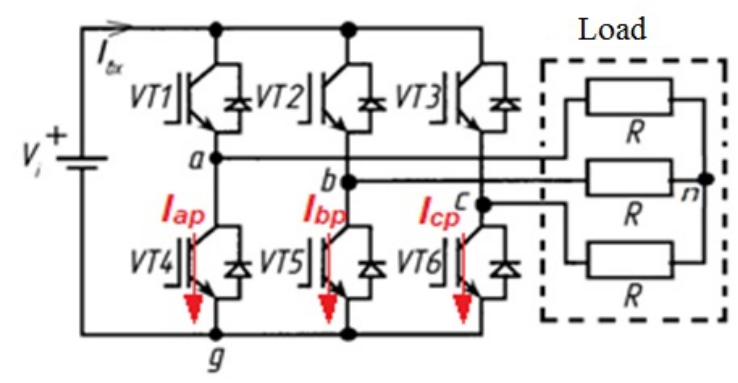

Fig. 1. Simplified scheme of autonomous voltage inverter with symmetrical active load

According to the geometric approach [3], the parameters that are input (independent) and output are set first. Leg voltages at points $a-g, b-g, c-g$ chosen for input parameters $U_{a}, U_{b}, U_{c}$. They represent a system of orthogonal vectors in three dimensions, which can be represented as sides of a "cube" (Fig. 2). Moreover, the vectors $U_{a}, U_{b}, U_{c}$ are basic, with which you can construct all other vectors of the "cube". The projections of the vectors $U_{a}, U_{b}$, $U_{c}$ on the plane form a system of output parameters $U_{a n}, U_{b n}, U_{c n}$ - load voltages. Herewith, one degree of freedom is lost [3], as a result we have two independent parameters and one dependent. At the same time, the projection of the vectors $U_{a}, U_{b}, U_{c}$ on one-dimensional space to form a vector of input current $\boldsymbol{I}_{\text {in }}$ (Fig. 2).

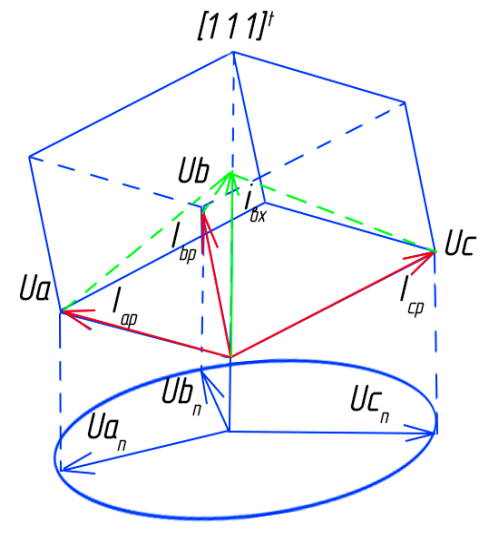

Fig. 2. Vector diagrams of spaces of input and output values

Inverter control does not allow simultaneous closure of switches in one leg, for example VT1 VT4 [2], [3]. The closure of only one of these switches is taken into account, so there are eight states of the inverter that generate the voltages and currents presented in Table I.

The formation of the transition matrix from input to output voltages is explained in detail in [3], [5]. Based on these works, the required matrix for the output voltages $U_{a n}, U_{b n}, U_{c n}$ has the form:

$$
\left[\begin{array}{l}
U_{a n} \\
U_{b n} \\
U_{c n}
\end{array}\right]=\frac{1}{3}\left[\begin{array}{ccc}
2 & -1 & -1 \\
-1 & 2 & -1 \\
-1 & -1 & 2
\end{array}\right] \cdot\left[\begin{array}{c}
U_{a} \\
U_{b} \\
U_{c}
\end{array}\right]=T_{k U} \cdot\left[\begin{array}{c}
U_{a} \\
U_{b} \\
U_{c}
\end{array}\right],
$$

where $T_{k U}$ is the transition matrix from the input voltages in three-dimensional space to the output voltages in the plane.

TABLE I STATES OF THE INVERTER

\begin{tabular}{|c|c|c|c|c|c|c|c|}
\hline$n$ & $U_{a}$ & $U_{b}$ & $U_{c}$ & $U_{a n}$ & $U_{b n}$ & $U_{c n}$ & $I_{i n}$ \\
\hline 1 & 0 & 0 & 0 & 0 & 0 & 0 & 0 \\
\hline 2 & 0 & 0 & $V_{i}$ & $-V_{i} / 3$ & $-V_{i} / 3$ & $2 V_{i} / 3$ & $2 V_{i} / 3 R$ \\
\hline 3 & 0 & $V_{i}$ & 0 & $-V_{i} / 3$ & $2 V_{i} / 3$ & $-V_{i} / 3$ & $2 V_{i} / 3 R$ \\
\hline 4 & 0 & $V_{i}$ & $V_{i}$ & $-2 V_{i} / 3$ & $V_{i} / 3$ & $\mathrm{~V}_{\mathrm{i}} / 3$ & $2 V_{i} / 3 R$ \\
\hline 5 & $V_{i}$ & 0 & 0 & $2 V_{i} / 3$ & $-V_{i} / 3$ & $-V_{i} / 3$ & $2 V_{i} / 3 R$ \\
\hline 6 & $V_{i}$ & 0 & $V_{i}$ & $V_{i} / 3$ & $-2 V_{i} / 3$ & $V_{i} / 3$ & $2 V_{i} / 3 R$ \\
\hline 7 & $V_{i}$ & $V_{i}$ & 0 & $V_{i} / 3$ & $V_{i} / 3$ & $-2 V_{i} / 3$ & $2 V_{i} / 3 R$ \\
\hline 8 & $V_{i}$ & $V_{i}$ & $V_{i}$ & 0 & 0 & 0 & 0 \\
\hline
\end{tabular}

Consider the formation of the input current vector $\boldsymbol{I}_{i n}$. To form the relationship between the input parameters by voltage and by output current, it is necessary first to create the transition matrix from input voltages to the corresponding equivalent currents $I_{a p}, I_{b p}, I_{c p}$ in three-dimensional space (Fig. 2).

By Table I on rows 2, 3, 5 we have:

$$
\left[\begin{array}{c}
I_{a p} \\
I_{b p} \\
I_{c p}
\end{array}\right]=\frac{1}{R} \cdot\left[\begin{array}{ccc}
1 & -1 & -1 \\
1 & 0 & 0 \\
0 & 1 & 1
\end{array}\right] \cdot\left[\begin{array}{c}
U_{a} \\
U_{b} \\
U_{c}
\end{array}\right]=T_{k R} \cdot\left[\begin{array}{c}
U_{a} \\
U_{b} \\
U_{c}
\end{array}\right],
$$

where $T_{k R}$ is the transition matrix from input (leg) voltages to corresponding currents.

The transition matrix from equivalent currents in the space of the "cube" belonging to the input voltages to the input current:

$$
I_{i n}=\left[\begin{array}{lll}
\frac{1}{3} & \frac{1}{3} & \frac{1}{3}
\end{array}\right] \cdot\left[\begin{array}{c}
I_{a p} \\
I_{b p} \\
I_{c p}
\end{array}\right]=T_{k I} \cdot\left[\begin{array}{c}
I_{a p} \\
I_{b p} \\
I_{c p}
\end{array}\right],
$$

where $T_{k I}$ is the transition matrix from currents $I_{a}, I_{b}, I_{c}$ to current $\boldsymbol{I}_{\text {in. }}$.

Substituting expression (1) in (2), we obtain:

$$
\begin{array}{r}
I_{\text {in }}=\left[\begin{array}{lll}
\frac{1}{3} & \frac{1}{3} & \frac{1}{3}
\end{array}\right] \cdot \frac{1}{R} \cdot\left[\begin{array}{ccc}
1 & -1 & -1 \\
1 & 0 & 0 \\
0 & 1 & 1
\end{array}\right] \cdot\left[\begin{array}{c}
U_{a} \\
U_{b} \\
U_{c}
\end{array}\right] \\
=T_{k I} \cdot T_{k R} \cdot\left[\begin{array}{l}
U_{a} \\
U_{b} \\
U_{c}
\end{array}\right],
\end{array}
$$


Thus, the transition matrices for the input current (3) and output voltages are obtained, which allow to further develop the inverter control system.

\section{SimUlation IN THE SOFTWARE SimUlinK}

The model of the inverter with a control system that operates on active load is shown in Fig. 3. The control system is based on the space-vector pulsewidth modulation (PWM), with some changes.

As mentioned in the introduction, one of the important tasks for building a control system is to increase the number of feedbacks. At the same time, the classic method of vector control of semiconductor converters is the use of a polar coordinate system, which leads to the loss of one degree of freedom [7], [10]. As a solution that prevents this phenomenon, it is proposed to use a spherical coordinate system that allows you to rotate the control vector in three-dimensional space.

As the power source of the inverter unit selected $D C$ Voltage Source. The three-phase inverter is built using blocks Mosfet, which are a field-effect transistor with a reverse diode, the control pulse is arrives to each transistor separately.

The developed control system is presented in Fig. 4. Most blocks under the mask implement program code of Matlab.

Transition from three-dimensional Cartesian coordinate system to rotating spherical, implemented by subsystem $g A B C$ Ref Generator. Sector selection is also implemented using code in the block Sector selection. It also allows you to calculate the length of the reference voltage vector and the angle of rotation of this vector. A similar block - Compute $T 1, T 2, T 0$ and pulses, allows you to calculate the duration of the PWM for each of the sectors. To simplify the calculations used some of the input parameters of the model: switching frequency Fs and supply voltage $V_{d c}$. The unit also generates pulses that go directly to the transistors.

The shape of the stresses on the load has a stepped shape with PWM, which with the subsequent use of smoothing filters will turn into a sinusoidal shape (Fig. 5).

The input current has the form of pulses of the same amplitude. To achieve the task set in the introduction, namely: consumption constant current from the source it is enough to use the input filter (Fig. 6). Moreover, when using a capacitor at the input of the inverter, the type of transition matrices and as a consequence, the algorithm of the control system will remain unchanged.

In creating a control system, the problem of losing the degree of freedom was solved by refusing to switch to the polar coordinate system. As a result, time diagrams of output voltages and currents are obtained, which correspond to the theoretical ones.

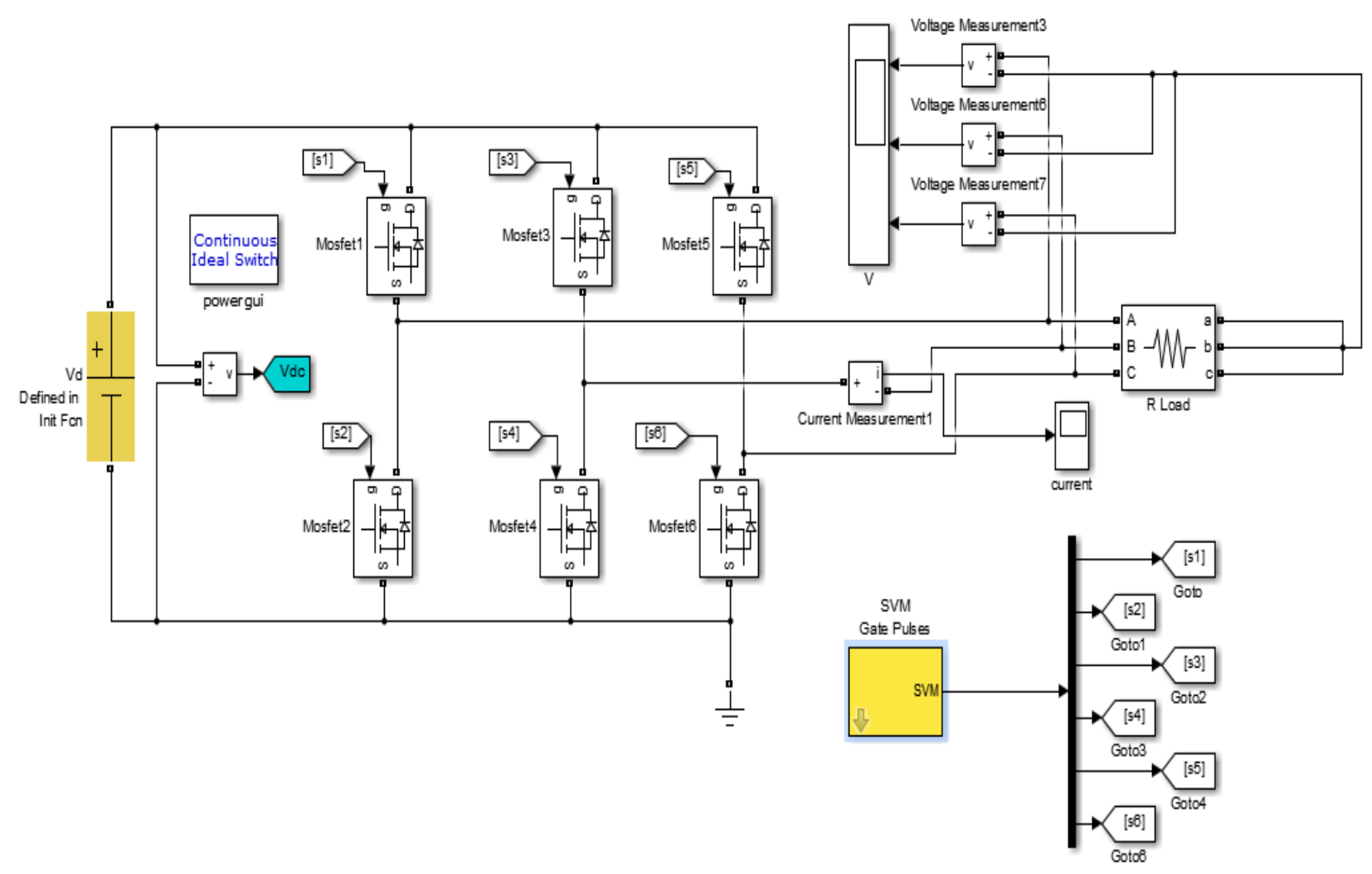

Fig. 3. Inverter model with control system 


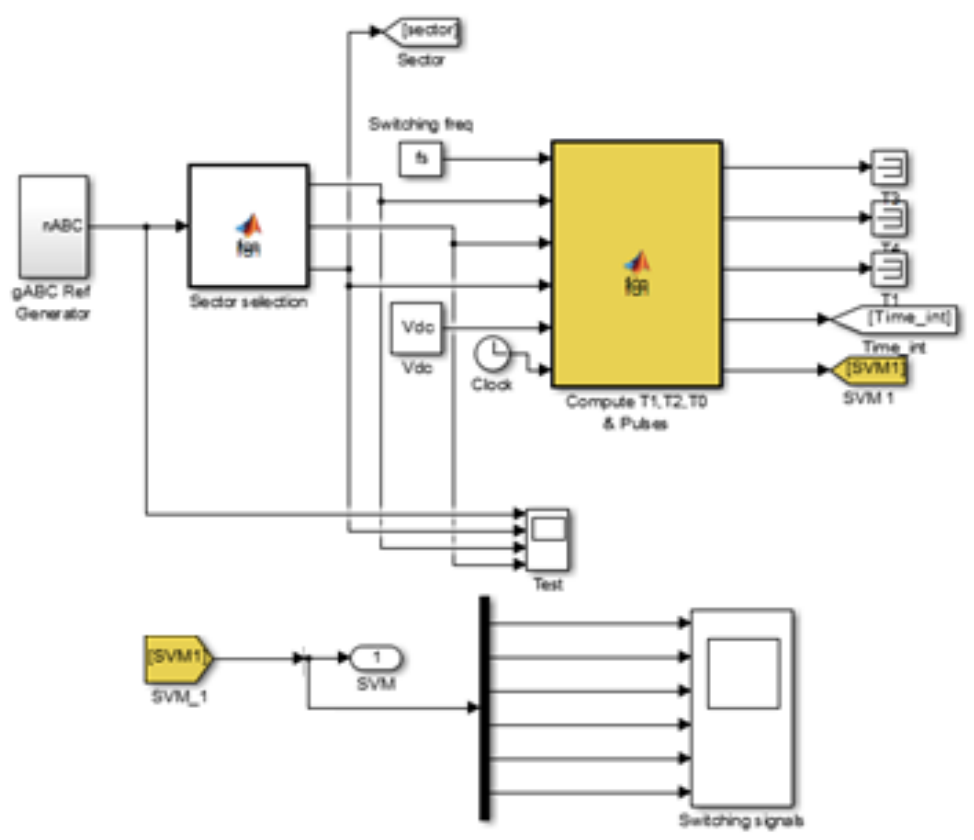

Fig. 4. Control system model
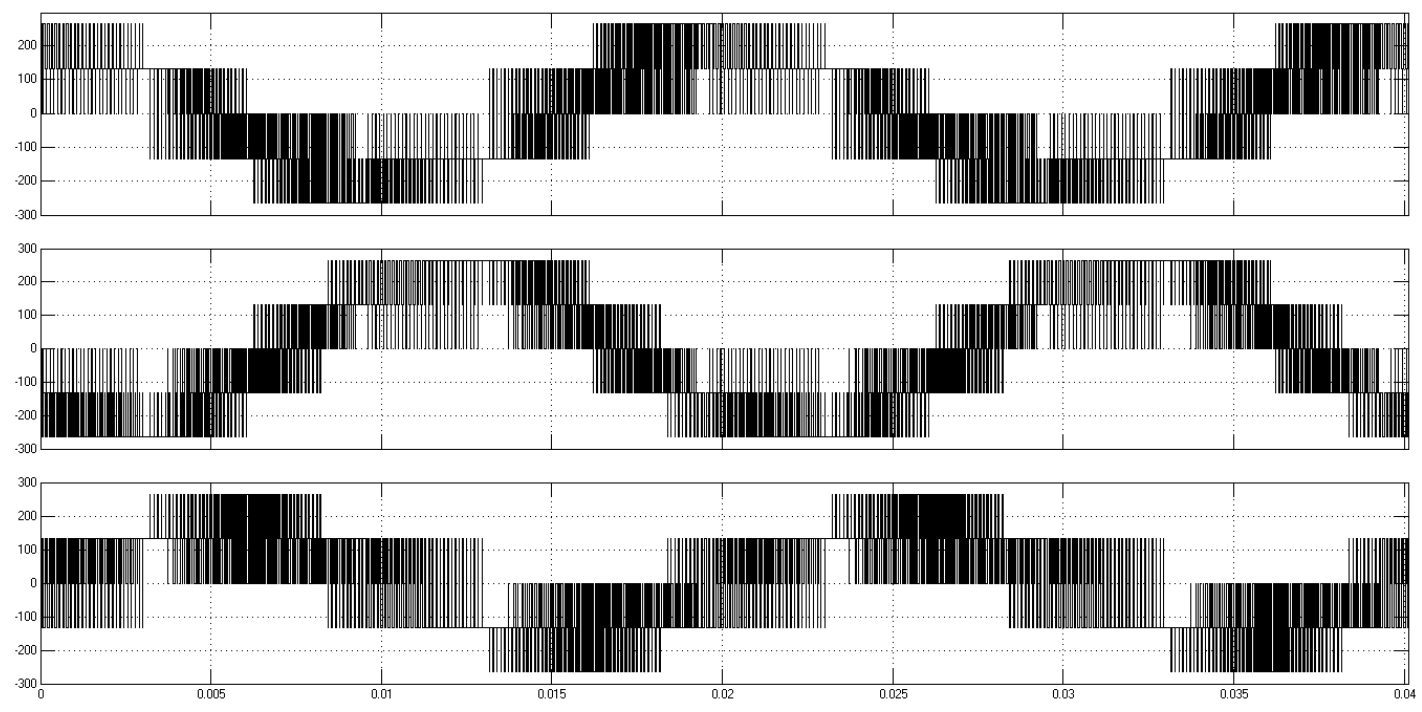

Fig. 5. Output voltage diagrams

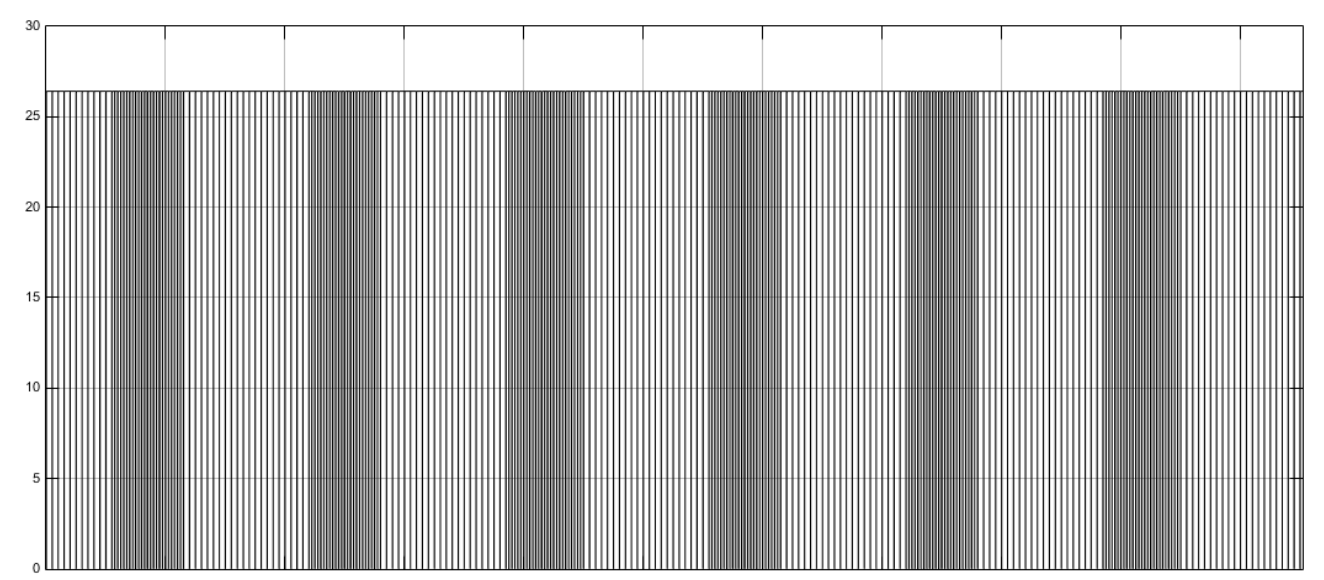

Fig. 6. Time diagram of input current 
It should be noted that when deriving the ratios, it was determined that the type of transition matrix for voltages does not depend on the type of load. At the same time, when deriving the transition matrix for currents, it is necessary to take into account the complex nature of the type of load, which is a separate task.

\section{CONCLUSIONS}

Using a geometric approach, a three-phase standalone inverter with symmetrical active load operation is analyzed. With the help of the relations presented in the article, in the future it is possible to apply this method to analyze the operation of the bridge inverter for real load, as which you can use mathematical models of an induction motor or network.

\section{REFERENCES}

[1] V. Zhuikov and K. Osypenko, "The stability of solar panel-diesel generator system," 2016 2nd International Conference on Intelligent Energy and Power Systems (IEPS), Kyiv, 2016, pp. 1-4. DOI:10.1109/IEPS.2016.7521844.

[2] D. A. Mykolaiets, "The use of a geometric approach for the analysis of a single-phase inverter," Microsystems, Electronics and Acoustics, vol. 24, no. 2, pp. 47-50. 2019. DOI:10.20535/25234455.2019.24.2.169796.

[3] M. J. Ryan, R. D. Lorenz, and R. De Doncker, "Modeling of multileg sine-wave inverters: a geometric approach," IEEE Trans. Ind. Electron., vol. 46, no. 6, pp. 1183-1191, 1999, DOI: 10.1109/41.808008.

[4] A. V. Soich and D. A. Mykolaiets, "The control of the frequency converter using a geometric approach," Microsystems, Electronics and Acoustics, vol. 24, no. 3 , pp. 39-44, 2019. DOI:10.20535/25234455.2019.24.3.172227.
[5] Y. S. Peterherya and O. V. Sobolev, "Construction of invariant control of the system by a matrix converter - an asynchronous motor based on a geometric approach," Electron. Commun., no. 10, pp. 140-143, 2001.

[6] Ievgen Verbytskyi, Anna Kyselova, and Gennadiy Kyselov, "Power grid converter control improvement based on contextual data," 2017 IEEE First Ukraine Conference on Electrical and Computer Engineering (UKRCON), 2017, pp. 599-604. DOI:10.1109/UKRCON.2017.8100311.

[7] V. M. Mikhalsky, V. M. Soboliev, V. V. Chopik, and I. A. Shapoval, "Keruvannia Avtonomnymy Invertoramy Napruhy iz Zabezpechenniam Maksymalnoho Koefitsiienta Moduliatsii Pry Nespotvoriuiuchomu Formuvanni Vykhidnoi Napruhy Zasobamy Modyfikovanoi ShIM," Tekhnichna Elektrodynamika, no.1, pp. 49-59, 2010. URL:http://www.techned.org.ua/article/10-1/st7.pdf

[8] V. Y. Zhuikov and D. A. Mikolaiets, "The Use of a Geometric Approach for Three-phase Active Power Line Conditioner," Tekhnichna Elektrodynamika, vol. 5, no. 5, pp. 35-38 2018, DOI: https://doi.org/10.15407/techned2018.05.035

[9] Y. S. Peterheria and O. V. Sobolev, "Primeneniye geometricheskogo podkhoda $\mathrm{k}$ analizu protsessov $\mathrm{v}$ matrichnykh preobrazovatelyakh [Application of a geometric approach to the analysis of processes in matrix converters]," Tekhnichna Elektrodynamika, no. 5, pp. 33-36, 2001. URL: http://www.techned.org.ua/index.php?option=com_c ontent\&view $=$ article\&id $=977 \&$ Itemid $=77$.

[10]V. Oleshchuk and V. Ermuratskyi, "Synkhronnoe Sbalansyrovannoe Rehulyrovanye Mnohofaznoi Systemy na Baze Shym-Ynvertorov s Fyksyrovannoi Neitralnoi Tochkoi," Tekhnichna Elektrodynamika, no. 5 , pp. 27-35, 2019. DOI: https://doi.org/10.15407/techned2019.05.027.

Received September 02, 2020.

Oleksii Yama. orcid.org/0000-0002-9234-1990.

Student.

Education: National Technical University of Ukraine "Igor Sikorsky Kyiv Polytechnic Institute", Kyiv, Ukraine.

Research area: geometric approach for the analysis of semiconductor converters.

Publications: 1 .

E-mail: alexei.yama@gmail.com

Dmytro Mykolaiets. orcid.org/0000-0002-9152-8593.

Candidate of Science (Engineering). Associate Professor.

Department of Electronic Devices and Systems, Faculty of Electronics, National Technical University of Ukraine "Igor Sikorsky Kyiv Polytechnic Institute,” Kyiv, Ukraine.

Education: National Technical University of Ukraine "Kyiv Polytechnic Institute”, Kyiv, Ukraine, (2011).

Research area: reactive power compensation, geometric approach for the analysis of semiconductor converters, the control systems for power supplies for electronic equipment.

Publications: more than 30 .

E-mail: d.mykolaiets@kpi.ua 


\section{О. С. Яма, Д. А. Миколаєць. Керування трифазним автономним інвертором напруги за допомогою геометричного підходу}

Для побудови різних систем електроживлення необхідно конструювання системи управління, яка забезпечувала б електромагнітну сумісність і з навантаженням, і з джерелом. Запропоновано застосовування геометричного підходу для опису напівпровідникових силових перетворювачів, який дозволяє з використанням незалежних вхідних змінних керувати вихідними параметрами. Проведено аналіз трифазного автономного інвертора 3 симетричним активним навантаженням за допомогою геометричного підходу. Побудовано систему векторів, на якій показані вектори вхідних величин в тривимірному просторі та їх проекції, що формують вихідні величини в двовимірному і одновимірному просторі. Створено таблицю, яка описує величини струмів та напруг в перетворювачі при відповідних станах вентилів. Вибрано три базові вектори, з використанням яких можливо отримати всі інші вектори вхідних величин. Отримано матриці переходу для вхідного струму та вихідних напруг. Побудована система керування автономним інвертором з використанням геометричного підходу. Основою є просторово-векторна ШІМ, з деякими змінами. В результаті була вирішена проблема втрати одного ступеня свободи шляхом відмови від полярної системи координат при переході на іншу систему координат. Рішенням стало введення сферичної системи координат, яка дозволяє обертати керуючий вектор в тривимірному просторі. В результаті отримані часові діаграми вихідних напруг і струмів, що відповідають теоретичним. Більшість блоків в системі керування під маскою реалізують програмний код Мatlab: перехід від тривимірної декартової системи координат до обертової сферичної, вибір сектору, довжина опорного вектора та величина кута, тривалість ШІМ для кожного сектора. Форма вихідних напруг має ступінчасту форму. Форма згенерованих струмів повторює форму вихідних напруг.

Ключові слова: геометричний підхід; трифазний інвертор; система ортогональних векторів.

Олексій Сергійович Яма. orcid.org/0000-0002-9234-1990.

Студент.

Освіта: Національний технічний університет України «Київський політехнічний інститут імені Ігоря Сікорського», Київ, Україна.

Напрям наукової діяльності: геометричний підхід для аналізу напівпровідникових перетворювачів.

Кількість публікацій: 1.

E-mail: alexei.yama@gmail.com

Дмитро Анатолійович Миколаєць. orcid.org/0000-0002-9152-8593.

Кандидат технічних наук. Доцент.

Кафедра електронних пристроїв та систем, Факультет електроніки, Національний технічний університет України «Київський політехнічний інститут імені Ігоря Сікорського», Київ, Україна.

Освіта: Національний технічний університет України «Київський політехнічний інститут», Київ, Україна, (2011).

Напрям наукової діяльності: компенсація реактивної потужності, геометричний підхід для аналізу напівпровідникових перетворювачів, системи керування для джерел живлення електронної апаратури.

Кількість публікацій: понад 30.

E-mail: d.mykolaiets@kpi.ua

\section{А. С. Яма, Д. А. Миколаец. Управление трехфазным автономным инвертором напряжения с помощью геометрического подхода}

Для построения различных систем электропитания необходимо конструирование системы управления, которая обеспечивала бы электромагнитную совместимость и с нагрузкой, и с источником. Предложено применение геометрического подхода для описания полупроводниковых силовых преобразователей, который позволяет с использованием независимых входных переменных управлять выходными параметрами. Проведен анализ трехфазного автономного инвертора с симметричной активной нагрузкой с помощью геометрического подхода. Построена система векторов, на которой показаны векторы входных величин в трехмерном пространстве и их проекции, формирующие выходные величины в двумерном и одномерном пространстве. Создано таблицу, которая описывает величины токов и напряжений в преобразователе при соответствующих состояниях вентилей. Выбрано три базовые векторы, с использованием которых можно получить все остальные векторы входных величин. Получены матрицы перехода для входного тока и выходных напряжений. Построена система управления автономным инвертором с использованием геометрического подхода. Основой является пространственно-векторная ШИМ, с некоторыми изменениями. В результате была решена проблема потери одной ступени свободы путем отказа от полярной системы координат при переходе на другую систему координат. Решением стало введение сферической системы координат, которая позволяет вращать управляющий вектор в трехмерном пространстве. В результате получены временные диаграммы выходных напряжений и токов, соответствующие теоретическим. Большинство блоков в системе управления под маской реализуют программный код Matlab: переход от трехмерной декартовой системы координат к вращающейся сферической, выбор сектора, длина опорного вектора и величина угла, продолжительность ШИМ для каждого 
сектора. Форма выходных напряжений имеет ступенчатую форму. Форма сгенерированных токов повторяет форму выходных напряжений.

Ключевые слова: геометрический подход; трехфазный инвертор; система ортогональных векторов.

Алексей Сергеевич Яма. orcid.org/0000-0002-9234-1990.

Студент.

Образование: Национальный технический университет Украины «Киевский политехнический институт имени Игоря Сикорского», Киев, Украина.

Направление научной деятельности: геометрический подход для анализа полупроводниковых преобразователей.

Количество публикаций: 1.

E-mail: alexei.yama@gmail.com

Дмитрий Анатольевич Миколаец. orcid.org/0000-0002-9152-8593.

Кандидат технических наук. Доцент.

Кафедра электронных устройств и систем, Факультет электроники, Национальный технический университет Украины «Киевский политехнический институт имени Игоря Сикорского», Киев, Украина.

Образование: Национальный технический университет Украины «Киевский политехнический институт», Киев, Украина, (2011).

Направление научной деятельности: компенсация реактивной мощности, геометрический подход для анализа полупроводниковых преобразователей, системы управления для источников питания электронной аппаратуры. Количество публикаций: более 30.

E-mail: d.mykolaiets@kpi.ua 